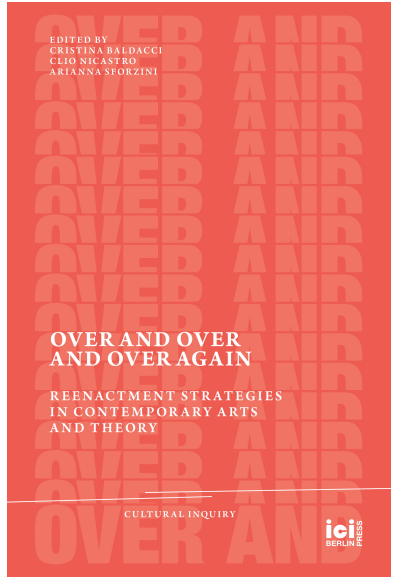

Over and Over and Over Again: Reenactment Strategies in Contemporary Arts and Theory, ed. by Cristina Baldacci, Clio Nicastro, and Arianna Sforzini, Cultural Inquiry, 21 (Berlin: ICI Berlin Press, 2022), pp. 37-46
PIO ABAD

\section{The Collection of Jane Ryan \& William Saunders} Reconstruction as 'Democratic Gesture'

CITE AS:

Pio Abad, 'The Collection of Jane Ryan \&' William Saunders: Reconstruction as 'Democratic Gesture", in Over and Over and Over Again: Reenactment Strategies in Contemporary Arts and Theory, ed. by Cristina Baldacci, Clio Nicastro, and Arianna Sforzini, Cultural Inquiry, 21 (Berlin: ICI Berlin Press, 2022), pp. 37-46 <https://doi.org/10.37050/ci-21_05>

\section{RIGHTS STATEMENT:}

(C) by the author(s)

Except for images or otherwise noted, this publication is licensed under a Creative Commons Attribution-ShareAlike 4.0 International License.

ABSTRACT: This paper focuses on an ongoing project that began in 2012, entitled The Collection of Jane Ryan \& William Saunders. This project is an attempt to reconstitute the Marcos Collection. Sourced from auction catalogues, museum archives, and scant government records, their lavish inventory of commissioned portraits, jewellery, Regency silverware, and old master paintings is reproduced as photographic installations, postcards, and three-dimensional prints. Reconstruction, in this instance, becomes a sustained democratic gesture, allowing an increasingly forgetful public to access a collection that has remained unavailable through a systemic failure by successive post-dictatorial governments to institutionalize collective acts of remembering.

KEYWORDS: Philippine history; collective memory; dictatorships; historical reconstruction 


\section{The Collection of Jane Ryan \& William Saunders}

Reconstruction as 'Democratic Gesture'

PIO ABAD

The Collection of Jane Ryan \& William Saunders is an ongoing project that I started in 2012. It focuses on the role that a collection of artefacts has played in the recent history of the Philippines, specifically on the cultural legacy of Ferdinand and Imelda Marcos, who ruled the country as a conjugal dictatorship - or what they preferred to call 'constitutional authoritarianism', and what I would prefer to call a kleptocracy — from 1965 to 1986.

Through a combination of wilful obfuscation and political convenience, this collection has been largely unavailable to the public. What has been recovered of the so-called Marcos Collection, a seemingly arbitrary assortment of old masters, Georgian and Regency-era silverware, and even one of the largest collections of Grandma Moses paintings, was sequestered by the government shortly after 1986. Some pieces were hidden away in storage, a few were displayed in government offices, and most were auctioned off. Thirty years later, a huge number of works of art remain unaccounted for, their existence proven only by metal plaques on the walls where the works used to be displayed or on inventories on yellowing pieces of paper proclaiming them lost. Over the past six years, my project has aimed to make the 


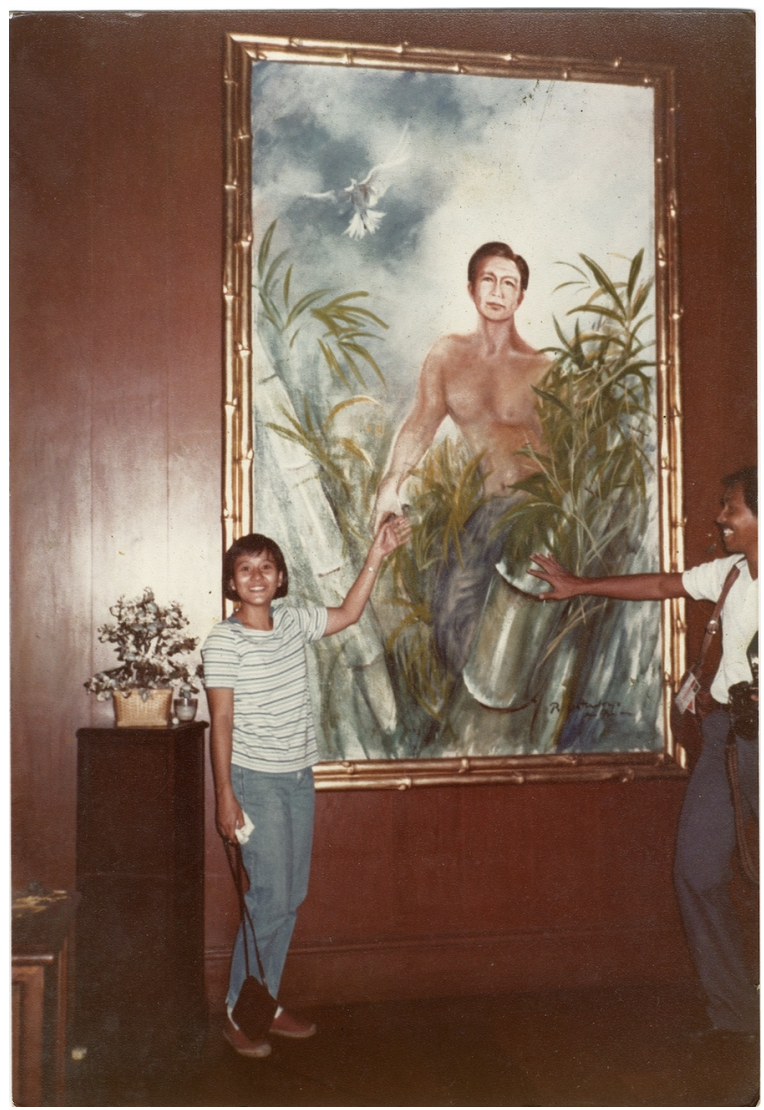

Figure 1. Photograph taken on 25 February 1986 in the Marcoses' private chambers at Malacañan Palace (1986).

collection accessible to the public by recreating this inventory using different strategies of reconstruction.

The genesis of this project can be traced to a family photograph. 'Genesis' is perhaps a particularly appropriate term given the subject of the painting in the photo. It depicts Ferdinand Marcos as the mythical figure Malakas. According to popular legend, Malakas (The Strong One) and Maganda (The Beautiful One) were the first Filipinos, who entered the world fully formed when a magical bird split a single stalk of bamboo in half, revealing the pair cradled inside. The Marcoses deployed this myth as the iconographic representation of their conjugal 
rule. Edenic images of the couple were fed into the propaganda machine and proliferated as murals and sculptures throughout the city. In assuming the personas of Malakas and Maganda, the Marcoses sought to mythologize the progress of history and present themselves as the originators of the circulation of cultural and political power. ${ }^{1}$

This photograph was taken by my mother on the evening of the 25 February 1986. A few hours before, Ferdinand and Imelda were chased out of the presidential palace and boarded one of Ronald Reagan's helicopters for a reluctant Honolulu exile. My mother and father, the figure on the right, were two of the first protesters to enter the private chambers. This photograph, I believe, is one of the earliest documentations of that exact moment when the public façade of Malakas and Maganda collapsed, and the people they had been oppressing for two decades suddenly had access to the sordid private life behind these misrepresentations. The Marcoses' modernist myth came at the cost of 3,257 lives, the torture and incarceration of 34,000 more - my parents among them - and the systematic ransacking of the national treasury, one of the largest thefts in history that exploited the then nascent system of offshore havens and shell companies.

At this historical juncture, replacing Malakas and Maganda with another set of alter egos will be more instructive. Jane Ryan and William Saunders, the characters from which this project takes its title, were the false identities used by Imelda and Ferdinand Marcos to register their first Swiss bank account at Credit Suisse Zurich in March 1968, and it was presumably through this dummy account and many others that the couple purchased art and property, skimmed off Japanese World War II reparations, donated a million dollars to each of Richard Nixon's presidential campaigns, and transformed foreign aid to private wealth. By the time they left office, investigators estimated their wealth at about ten billion US dollars ${ }^{2}$.

The scale of the Marcoses' loot is so vast and so astonishing in range that it is often only referred to in collective terms such as 'loot',

1 Vicente Rafael, 'Patronage and Pornography: Ideology and Spectatorship in the Early Marcos Years', Comparative Studies in Society and History, 32.3 (1990), pp. 282-304.

2 Nick Davies, 'The \$10bn Question: What Happened to the Marcos Millions', Guardian, 7 May $2016<$ https://www.theguardian.com/world/2016/may/07/10bn-dollarquestion-marcos-millions-nick-davies $>$ [accessed 22 February 2021]. 
'plunder', and 'ill-gotten wealth'. So much so that over time, it has assumed, in its status as a collective noun, an almost abstract singularity - a single object that is subsequently easier to disregard, trivialize, and contain within one of Imelda's stilettos. One of my main objectives behind this project was to wrest this loot from that collective singularity and confront the public with its unwieldy scale and its terrifying range.

Over the past few years, I have used a number of strategies to reconstruct this collection. In 2012, when I was researching for the project's first iteration at Gasworks in London, I came across catalogues of two Christie's auctions held in New York on 10 and 11 January 1991. Acting on behalf of the Philippine Commission on Good Government (PCGG), the agency tasked with the sequester and the liquidation of the Marcoses' wealth, Christie's auctioned off seventy-eight lots of Georgian and Regency-era silverware, at the time the largest collection of silverware from a single collection, and seventy-eight Renaissance paintings of inconsistent quality (and, as discovered later on, dubious provenance). In addition to these, twenty-five old masters paintings of arguably superior quality, which were confiscated from a yacht owned by the Saudi arms dealer Adnan Kashoggi, were being sold by the US Federal Government. It was alleged that Kashoggi was hiding these works for Mrs. Marcos.

These images became the basis for exploring the idea of exhibition making as medium - museological display as armature for creating photographic installations and sculpture. It also served as a way of restaging my earliest memories of a museum, an experience irrevocably tied to the fall of the Marcos dictatorship.

The hastily constructed museum of personal effects is a postrevolutionary trope in freshly liberated autocracies, and for a number of years after the revolution the basement of the presidential palace was turned into a provisional museum. At six years old, I vividly remember walking through rows and rows of mahogany shelves and table tops, each one filled with various items: paintings, ornaments, perfume bottles, bulletproof brassieres, and the infamous pairs of shoes.

Unfortunately, the fragile democracies that follow revolutions are accompanied by another trope: the systemic failure to institutionalize collective acts of remembering that displays such as these were meant to engender. By 1990, the political compromises of the new govern- 


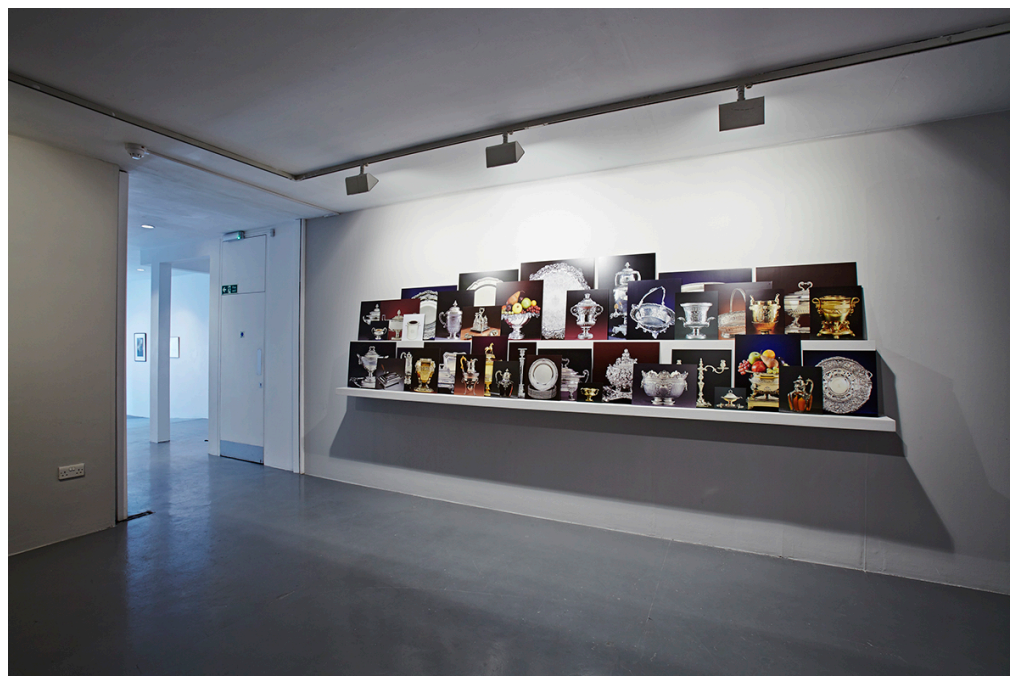

Figure 2. The Collection of Jane Ryan \& William Saunders (2014), Thirty-eight archival inkjet prints on Epson semi-gloss paper, mounted on aluminium, installation view (Gasworks, London).

ment and the convenient shifts in allegiances by many of the Marcoses' cronies meant that, by the time this museum was packed away, the clamour for political accountability by an exhausted and disillusioned public seemed to have gone with it.

I was interested in using the auction catalogues as the basis for excavation for a number of reasons. Firstly, the Christie's catalogue provides such a crisp and extensive visual accounting of the Marcos Collection that even the PCGG uses it as one of its primary points of reference. Before coming across the catalogues, a lot of the documentation I had found, if I could access it, was of poor quality. The rest I had imagined as buried under the bureaucratic and legal entanglements of the past thirty years.

Another reason for my interest was the timing of the event itself, taking place in between two defining, if unfortunate, episodes. A few months prior to the auction, Imelda Marcos was indicted by the Federal Court in New York City for fraud and racketeering charges. Imelda's tearful performance as a naïve widow during the trial was sensational. It was a performance that also proved convincing. After a 
four-month trial, the jury decided that the late Ferdinand Marcos had looted the Philippine treasury without the explicit knowledge of his wife. On 3 July 1990, Imelda was acquitted of all charges. Immediately after the verdict, she headed to St. Patrick's Cathedral and proceeded to creep down the entire aisle to the altar on her knees.

A few months after the auction and as a result of the acquittal, the Philippine government decided that there were no longer any legal impediments to bar Imelda's return to the Philippines. On 4 November 1991, an unrepentant Imelda returned home and would eventually be elected back into political office, along with two of her children. In the recent 2016 presidential elections that saw the rise of Rodrigo Duterte, Ferdinand Marcos, Jr., nicknamed 'Bongbong', nearly captured the vice presidency. In November of that same year, the newly installed President Duterte fulfilled a personal promise to the Marcoses by allowing the body of the dictator Ferdinand to be secretly interred at the National Hero's Cemetery.

Viewed in the context of these events, the auction, by dispersing the Marcos Collection and recirculating it back into the market, also served to launder these objects, silencing the historical narrative by which they are tainted. The museological installation and its accompanying text became a means of reconstituting this collection and reiterating its complicity to this history of corruption.

In his writings on art during the Marcos regime, the Filipino art historian Patrick Flores uses the term 'democratic gesture' in relation to the development of avant-garde practices in the Philippines during the $60 \mathrm{~s}$ and $70 \mathrm{~s}^{3}$ As 'the connoisseur of the new, a patroness of the avant-garde, and an arbiter of experiments in the arts, ${ }^{4}$ Imelda favoured conceptualism, as she did not see any conflict between its aesthetics and the American-coddled authoritarianism of her and her husband's government. As an art form, it served as a sophisticated retort to the more activist inclinations of social realist painting, reiterating the regime's idea of ethno-modernity and development and fitting perfectly with the rhetoric of progress that the Marcoses brazenly

3 Patrick Flores, 'Total Community Response: Performing the Avant-Garde as a Democratic Gesture in Manila', Southeast of Now: Directions in Contemporary and Modern Art in Asia, 1.1 (2017), pp. 13-38.

4 As described by the writer and Philippine National Artist Nick Joaquin. 


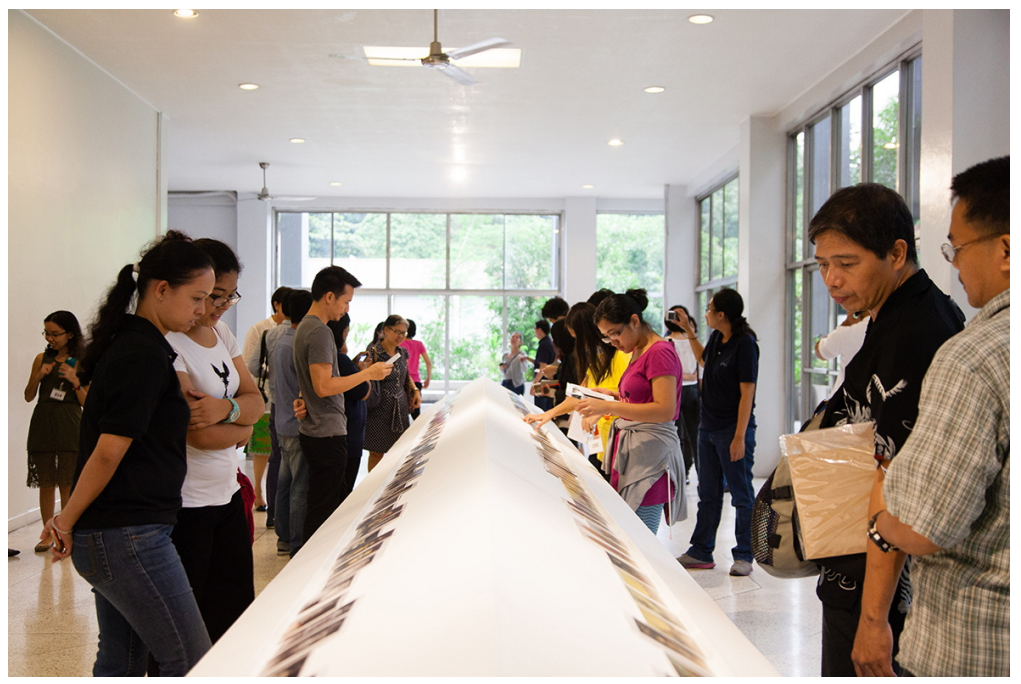

Figure 3. The Collection of Jane Ryan \& William Saunders (2014), 97 sets of postcards, unlimited edition, installation view (Jorge B. Vargas Museum, Manila).

asserted. The Cultural Centre of the Philippines, a Brutalist building that Imelda constructed on reclaimed land along Manila Bay, became the main edifice for arts and culture during the regime, serving as the institutional site for experimental performance, installations, and film. It did not seem to matter that all of this was taking place under martial rule and amidst the repressed bodies of its citizens.

The weaponized nature of the term 'democratic gesture' in relation to the Marcoses' support of avant-garde and conceptual practices has become central to the development of The Collection of Jane Ryan \& William Saunders. Central to the project is the desire to reclaim this definition of a 'democratic gesture' from Imelda's perverted appropriation.

The Gasworks exhibition was shown concurrently with my first museum presentation in Manila at the Jorge B. Vargas Museum at the University of the Philippines. For a Filipino audience, it became important that the work was participatory. For most, if not all, of the visitors to the exhibition it would serve as their most extensive encounter with the Marcos loot. Deploying participation as a conceptual 
strategy in the work also served to highlight the muted political agency in avant-garde practices prevalent during the time of the dictatorship.

I presented the paintings as postcards laid out on a ten-metre long white plinth that spanned the length of one of the rooms in the museum. The idea was to present an installation in an almost forensic fashion - a monumental body of incontrovertible evidence neatly arranged for scrutiny. On the back of each postcard is a series of seven different texts lifted from various sources, tracing the fraudulent history of this collection and implicating an expansive network of players from the worlds of art and politics.

The democratic gesture is performed by inviting the public to take ownership of the artworks and create their own personal collection of paintings from the postcard reproductions - a symbolic restitution of a collection purchased with the hard-earned money of, but never enjoyed by, the Filipino public.

The final part of this project concerns the collection of jewellery seized by US Customs from the Marcoses when they entered Hawaii in 1986, appropriately referred to in courts as the Hawaii Collection. The collection includes an extremely rare 25-carat pink diamond worth five million dollars and a tiara with twenty-five pearls in a diamond frame seized from the Russian Tsar's family in 1918.

Shortly after their seizure, the collection was turned over to the PCGG. Since then, they have languished in the vaults of the Central Bank, hidden from public view, amidst legal challenges from the Marcos family. In February 2016, the PCGG announced that all legal impediments had been cleared for the pieces to go to auction with a planned public exhibition to precede the sale. The victory of Rodrigo Duterte in May 2016 put these plans on hold. His administration announced plans to begin dismantling the PCGG with its responsibilities being transferred to the Office of the Solicitor General, a position currently held by a Marcos loyalist.

In collaboration with jewellery designer Frances Wadsworth Jones, we have digitally reconstructed the collection from photos obtained from the PCGG in early 2016 and created 3D printed replicas out of translucent resin. This iteration of the project was recently exhibited in Hawaii as part of the second Honolulu Biennial. Returning to the site of the Marcoses' short-lived exile, the jewellery 


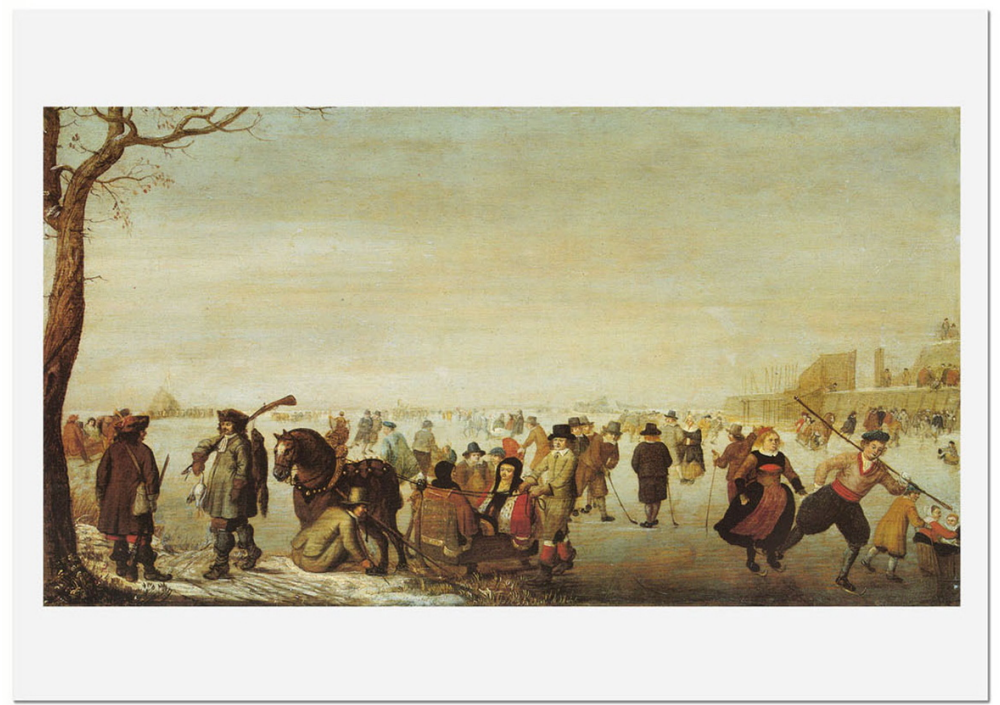

The Marcos Collection: Fortune and Folly Artnews Magazine, October 1990

Investigators say that just as the Marcos government was toppling, someone, or some group, emptied the 66th Street town house, the Olympic Towers apartment, and the other Marcos residences of much of their most valuable contents before the properties were seized.

Nothing on the record indicates where the 38 paintings Khashoggi bought were kept during the interim, but investigators did pick up their trace in the person of Khashoggi's sometime Manhattan chauffeur, Ernest Sabatino.

On May 19, 1986, Sabatino testified, he got a call from a Khashoggi aide who told him to rent a small truck 'and wait for a call from someone named Irene.' Something had to be delivered to Khashoggi's private plane, a Boeing 727, then parked at the Butler Aviation Terminal at Newark Airport. 'Irene' called, Sabatino continued, and he was told to drive to a mall in DOuglaston, Queens, and turn the truck over to two men while he waited in a parking lot. When the two men returned with the truck, he was to drive it to Khashoggi's plane.

Everything went according to plan, said Sabatino, adding that he never learned the identity of the men nor the contents of the truck.

When the men asked him to sign a receipt, what 'looked like names and titles,' said Sabatino, he refused. 'I didn't load the truck,' he said. The two men told him not to worry about it, Sabatino continued. 'So I just signed Mickey Mouse.'

'You signed Mickey Mouse?' roared Judge F. Keenan in astonishment when he heard the testimony.

'I literally signed Mickey Mouse,' Sabatino replied, adding that on his way to Newark Airport, he had parked the truck unattended on a Manhattan side street while he stopped to get some Chinese food.

Figure 4. The Collection of Jane Ryan \& William Saunders (2014), 97 sets of postcards, unlimited edition (detail). 


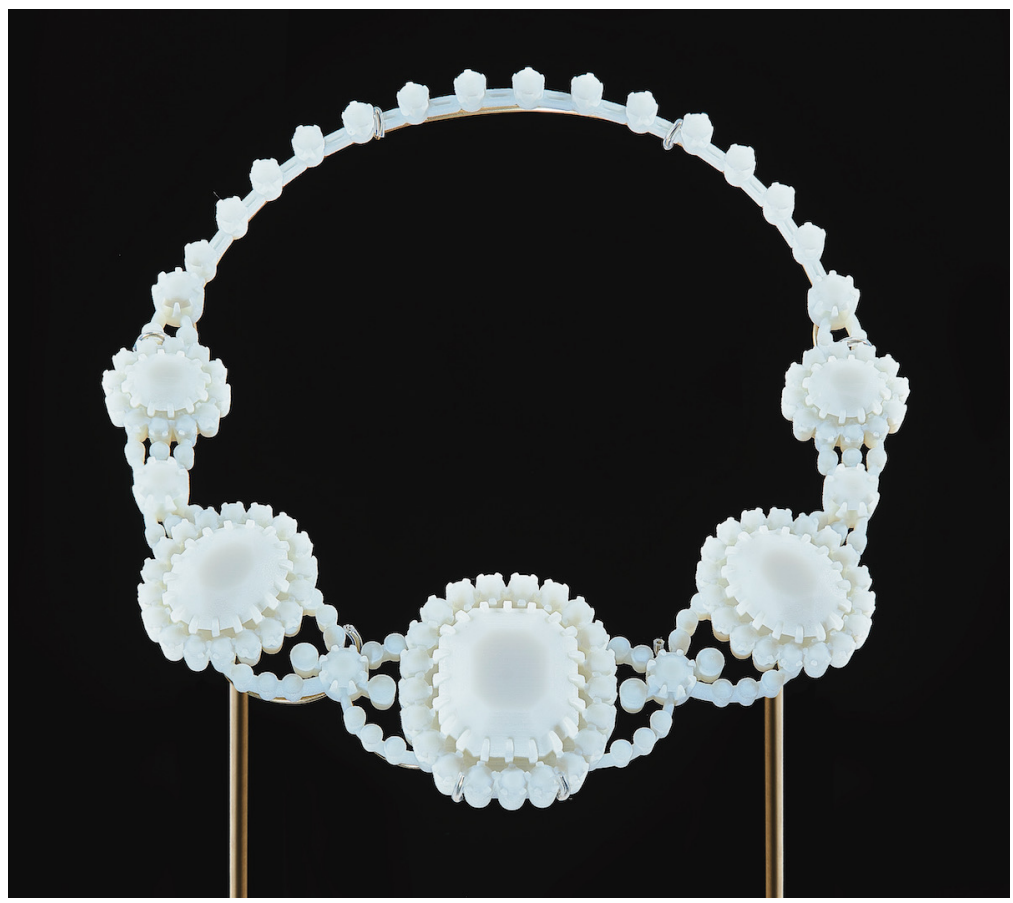

Figure 5. The Collection of Jane Ryan \& William Saunders (2019). $3 \mathrm{D}$ printed plastic, brass and dry-transfer text (detail).

reappears not as a collection of luxurious objects but as effigies ghosts of a history condemned to be in a perpetual state of irresolution.

Over the course of working on The Collection of Jane Ryan \& William Saunders, the Philippines has moved from a democracy, however flawed and chaotic, to once again being on the precipice of a much more violent dictatorship. This has made continuing with this project a difficult, if not perilous, endeavour, but it has also intensified the urgency to reconstruct this collection at a time when the cost of forgetting is too great a price to pay. 
Pio Abad, 'The Collection of Jane Ryan \& William Saunders: Reconstruction as 'Democratic Gesture', in Over and Over and Over Again: Reenactment Strategies in Contemporary Arts and Theory, ed. by Cristina Baldacci, Clio Nicastro, and Arianna Sforzini, Cultural Inquiry, 21 (Berlin: ICI Berlin Press, 2022), pp. 37-46<https://doi.org/10.37050/ci-21_05>

\section{REFERENCES}

Davies, Nick, 'The \$10bn Question: What Happened to the Marcos Millions', Guardian, 7 May 2016 <https://www.theguardian.com/world/2016/may/07/10bn-dollar-questionmarcos-millions-nick-davies $>$ [accessed 22 February 2021]

Flores, Patrick, 'Total Community Response: Performing the Avant-Garde as a Democratic Gesture in Manila', Southeast of Now: Directions in Contemporary and Modern Art in Asia, 1.1 (2017), pp. 13-38 <https://doi.org/10.1353/sen.2017.0001>

Rafael, Vicent, 'Patronage and Pornography: Ideology and Spectatorship in the Early Marcos Years', Comparative Studies in Society and History, 32.3 (1990) < https://doi.org/10.1017/ S0010417500016492> 